\title{
ОСОБЛИВОСТІ ПРОВЕДЕННЯ ЛЕКЦІЙНИХ ЗАНЯТЬ 3 РОЗДІЛУ “ЗАХВОРЮВАННЯ СЛИЗОВОЇ ОБОЛОНКИ РОТОВОЇ ПОРОЖНИНИ” ДЛЯ СТУДЕНТІВ-ІНОЗЕМЦІВ
}

\author{
І. О. Суховолець
}

ДВНЗ “Тернопільський державний медичний університет імені І. Я. Горбачевського МОЗ України”

\section{THE SPECIFICS OF LECTURING OF THE CHAPTER “DISEASES OF MUCOUS MEMBRANE OF ORAL CAVITY” FOR FOREIGN STUDENTS}

\section{O. Sukhovolets}

\author{
I. Horbachevsky Ternopil State Medical University
}

\begin{abstract}
У даній статті описані особливості проведення лекційних занять з розділу “Захворювання слизової оболонки ротової порожнини” для студентів-іноземців стоматологічного факультету. Описано й обґрунтовано переваги використання мультимедійних технологій та запропоновано методику проведення лекцій, яка сприятиме підвищенню концентрації студентів на матеріалі та кращому його запам’ятовуванню.
\end{abstract}

In this article there were described the specifics of lectures leading of the chapter "Diseases of mucous membrane of oral cavity" for the dental faculty foreign students. There were explained the advantages of multimedia technologies in lecturing and was proposed the method of lecture reading, which can increase student s concentration on lecture material and better remembering.

Вступ. Модернізація навчального процесу у вищій медичній школі - це постійний закономірний процес, без якого не можливий розвиток науки загалом та підготовка висококваліфікованих фахівців, здатних зайняти своє місце у світовій спільноті медиків. Незважаючи на різницю у методиках викладання та системах, що базуються на цих методиках у різних навчальних закладах світу, важливою складовою навчального процесу залишається лекція. В час активно прогресуючих технологій, що надають доступ до великої кількості інформації, особливо важливим є зацікавити студентів та сконцентрувати їхню увагу на актуальності обговорюваної проблеми, даючи їм можливість продовжити пошук інформації самостійно, відсіюючи непотрібне.

Основна частина. Особливістю розділу “Захворювання слизової оболонки ротової порожнини” є надзвичайно велика кількість інформації та її складність, що поглиблюється частою недостатністю тематичних пацієнтів (оскільки розділ включає в собі вивчення проявів багатьох як системних патологій, так і інфекційних захворювань у порожнині ротової

(c) І. О. Суховолець порожнини), тому вимагає наявності в студента попередньої бази знань з інших дисциплін. Саме це $є$ причиною вивчення його на останньому курсі навчання на стоматологічному факультеті. Поява мультимедійних технологій допомогла значно підвищити ефективність викладання цієї дисципліни, а особливо студентам-іноземцям, що зазвичай краще адаптовані до навчання 3 використанням електронних носіїв інформації, ніж фізичних $[1,2]$.

Основну увагу при викладенні матеріалу в даному розділі слід акцентувати на діагностиці захворювань, оскільки часто лікування їх відбувається за допомоги спеціалістів з інших галузей медицини або ж виключно ними, залишаючи стоматологу симптоматичне лікування. Незважаючи на це, саме стоматологи не тільки часто бувають першими, хто виявляє такі серйозні патології, як рак ротової порожнини чи ВІЛ/СНІД, а й мають змогу значно полегшити життя пацієнта, активно впливаючи на симптоми в ротовій порожнині, що лікарі загального профілю часто упускають, концентруючись на основному захворюванні. Також деякі патології, такі, наприклад, як хейліти та глосити, або ж стоматити, хоч і є часто 
пов’ язані з проявами системних захворювань, проте єдиним фахівцем, що буде відповідальним за їх лікування, залишається стоматолог. Навіть за умов вузької спеціалізації лікаря-стоматолога (такої, як реставрації чи ендодонтія) він повинен при первинному обстеженні вміти вчасно виокремити присутню патологію, встановити попередній діагноз та призначити необхідні додаткові методи обстеження, навіть зважаючи на те, що лікуванням буде займатись інший спеціаліст. На цьому необхідно наголосити, формулюючи актуальність лекції, мотивуючи студентів зрозуміти важливість комплексного підходу до діагностики та лікування захворювань ротової порожнини.

Зважаючи на великий об’єм інформації та часто низьку інформаційну якість її для студентів, що проявляється в неможливості виявити вивчені в підручнику симптоми в пацієнта, на практиці, чи розпізнати їх по часто незрозумілих для них описах (“вигляд сирого м’яса”, “малюнок мережива”), мультимедійна презентація лекції якнайкраще реалізує принцип “краще один раз побачити, ніж сто раз почути”. Це підтверджено й результатами досліджень, що вказують на підвищення сприйняття інформації з залученням зорового подразника з 15 до 65 \%. Таким чином, основний вміст лекції, на нашу думку, повинні становити малюнки та схеми, залишаючи текстову частину для озвучення, а не зорового сприйняття. Отже, після висвітлення, наприклад, шкірного симптому захворювання важливо візуалізувати його в презентації. Доцільним також вбачається показати фото не тільки характерних проявів висипу чи інших патологічних елементів, а й нетипових, наголошуючи на тому, як саме можна розпізнати за ними захворювання. Часто студенти плутають схожі патологічні елементи, виділяючи тільки одну їх характеристику (колір чи форму), тому показуючи декілька схожих проявів можна вказати, в чому полягає їх відмінність і як найшвидше її виявити. Диференційна діагностика $є$ найважливішою частиною постановки діагнозу, на чому і необхідно наголосити. Для кращого засвоєння також доцільним буде викладати основну інформацію тезами, що сприятиме її структуруванню, а отже, і запам’ятовуванню. Досить добре сприймаються студентами і короткі відео, що висвітлюють окремі моменти з патогенезу захворювання, обстеження пацієнта чи одного з методів лікування. Важливим, проте, $є$ не перевантажувати лекцію відеоматеріалом, що може відсунути лектора на другий план та спричинити втрату уваги студентів.
Студенти-іноземці, особливо з арабських країн, мають схильність персоналізувати викладача, що виливається в сприйнятті чи несприйнятті інформації загалом саме через сприйняття чи несприйняття конкретного лектора. За таких умов зацікавити студентів та сконцентрувати їхню увагу на проблемі допоможуть актуальні чи цікаві випадки з практики самого викладача. Навіть один чи два випадки в декількох фото з викладенням діагностики захворювання та поясненнями стосовно підбору лікування в конкретному випадку значно підвищать авторитет лектора перед аудиторією та покращать запам’ятовування. Щоб активізувати пізнавальну активність студентів та глибше залучити їх до процесу, можна перед поясненням власного вибору методу лікування запитати думку стосовно цього в аудиторії.

Підготовка лекції для іноземних студентів вимагає від лектора особливої уваги та концентрації, оскільки значно більше часу займає адаптація матеріалу [3, 4]. Відмінність класифікацій, різні протоколи лікування та назви медикаментів можуть легко заплутати студента та унеможливити його подальше самоопрацювання матеріалу. Погіршується ця проблема і проведенням вивчення матеріалу нерідною англійською для більшості студентів мовою, якою велика частина студентів володіє все-таки не ідеально, що може потребувати додаткових пояснень якихось висловів чи симптомів. Зважаючи на це, актуальним є висвітлення і вітчизняних і світових як класифікацій, так і протоколів лікування, пояснення зв’язку між ними, схожого і відмінного, подання іноземних аналогів ліків нарівні з українськими тощо, що допоможе студентам не “загубитися” у великому об’ємі інформації та використати її з користю і після повернення на батьківщину.

Беручи до уваги складність даного предмета, важливим $є$ також акцентувати увагу на практичному застосуванні викладеної інформації, а саме конкретизувати необхідний перелік додаткових методів дослідження для діагностики тієї чи іншої патологї, або надати детальну схему іï лікування з вказуванням конкретних препаратів, звертаючи меншу увагу на історичні аспекти чи статистичні дані, а також інформацію, яка напряму не стосуватиметься саме стоматологічного лікування [5].

Вищезазначені особливості підготовки та проведення лекцій були сформульовані, грунтуючись на багаторічному досвіді проведення 
мультимедійних презентацій для студентівстоматологів іноземного факультету з вказаного розділу. Такі презентації $є$ хорошою базою для подальшого поглиблення знань студентів на практичних заняттях з терапевтичної стоматології у розділі “Захворювання слизової оболонки ротової порожнини”.

Висновок. Проведення мультимедійних лекцій дозволяє суттєво покращити якісь освітнього процесу та значно поглибити розуміння студентами

\section{Список літератури}

1. Роль сучасних технологій у становленні майбутніх лікарів / В. М. Ждан, В. М. Бобирьов, О. В. Шешукова [та ін.] // Медична освіта. - 2012. - № 3.- С. 35-37.

2. Бойцанюк С. І. Організація лекційного процесу для студентів стоматологічного факультету в умовах навчання за кредитно-модульною системою / С. І. Бойцанюк // Медична освіта. - 2014. - № 1. - С. 10-12.

3. Мудра А. Є. Особливості викладання медичної біохімії студентам-іноземцям / А. Є. Мудра, О. Є. Олещук // Медична освіта. - 2014. - № 3. - С. 108-110. складних дисциплін, а також систематизувати та структурувати великі об’єми інформації, що сприятиме їі кращому запам'ятовуванню та використанню в подальшій практичній діяльності. При вивченні розділу “Захворювання слизової оболонки порожнини рота” студентами-іноземцями важливо зважати на мовний бар’єр та відмінності у класифікаціях та назвах захворювань, які можуть завадити їм засвоїти необхідний об’єм знань.

4. Корда М. М. Навчання іноземних студентів в Тернопільському державному медичному університеті ім. І. Я. Горбачевського: історія і перспективи / М. М. Корда // Медична освіта. - 2012. - № 1. C. $113-123$.

5. Косенко К. М. Методичні аспекти формування у студента-стоматолога практичних навичок та вмінь / К. М. Косенко // Вісник стоматології. - 2006. - № 3. C. 89-90. 